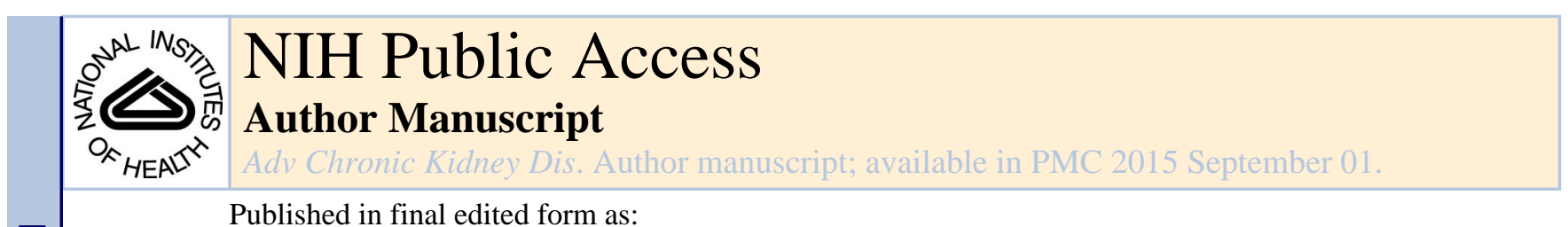

Published in final edited form as:

Adv Chronic Kidney Dis. 2014 September ; 21(5): 422-425. doi:10.1053/j.ackd.2014.06.001.

\title{
Familial FSGS
}

Martin R. Pollak

Beth Israel Deaconess Medical Center, 99 Brookline Ave, Boston, MA 02215, 617-667-0461, 617-667-0495 (fax)

Martin R.Pollak: mpollak@bidmc.harvard.edu

\section{Abstract}

FSGS and nephrotic syndrome can be caused by rare highly penetrant mutations in number of genes. FSGS can follow both recessive and dominant inheritance patterns. In general, recessive forms present early, while the autosomal dominant forms present in adolescence or adulthood. Many of the genes found to be mutated in FSGS and nephrotic syndrome patients encode proteins essential for normal podocyte structure and or function. An exception appears to be APOL1, which harbors common variants responsible for the high rate of FSGS and other nephropathies in people of recent African ancestry. Familial FSGS should be regarded as part of a spectrum of inherited glomerulopathies where the precise histologic presentation may depend on age of onset, function of the responsible gene and gene products, as well as other factors.

\section{Keywords}

FSGS; Genetic

FSGS is a pathologic rather than a diagnosis. In discussing "familial FSGS" it is easy to lose sight of this fact. A broad range of genetic and non-genetic factors can lead to kidney injury that manifests as focal and segmental scarring of the kidney's glomeruli. A common theme in these familial forms appears to be alterations in the glomerular podocyte's structure and/or function. It is commonplace to divide disease-altering genetic variants into two main groups: rare highly penetrant changes in DNA that cause Mendelian forms of disease, and common genetic variation that underlie common disease-related phenotypes. There is increasing interest in the notion that rare variants may also help explain risk for more common diseases. We will focus here largely on the highly penetrant forms of FSGS and also the related "podocytopathies" which cause early onset nephrotic syndrome (NS).

Inherited FSGS and NS can be broadly divided into early onset recessive disorders and later onset autosomal dominant disorders. As a general rule, the recessive forms of FSGS and NS are caused by loss of function mutations and present in infancy or early childhood. By

(C) 2014 The National Kidney Foundation, Inc. Published by Elsevier Inc. All rights reserved.

The author reports no conflicts of interest.

Publisher's Disclaimer: This is a PDF file of an unedited manuscript that has been accepted for publication. As a service to our customers we are providing this early version of the manuscript. The manuscript will undergo copyediting, typesetting, and review of the resulting proof before it is published in its final citable form. Please note that during the production process errors may be discovered which could affect the content, and all legal disclaimers that apply to the journal pertain. 
contrast, most of the dominant forms of FSGS are caused by gain-of-function mutations and are characterized by later onset, slowly progressive disease.

\section{Autosomal Dominant FSGS}

Point mutations in several genes lead to autosomal dominant kidney disease characterized by proteinuria, progressive CKD, and FSGS. Mutations in INF2, for Inverted Formin 2, appear to be the most common of these ${ }^{1-4}$. INF2 is a member of the formin family of actin polymerizing molecules. INF2 is unique in its ability to both accelerate actin polymerization and depolymerization. Formins are able to autoinhibit their activity by an intramolecular interaction between two domains, the N-terminal DID (diaphanous inhibitory domain) and the C-terminal DAD (diaphanous autoregulatory domain). For most formins studied, binding of a small GTPase to the N-terminus near the DID can relieve this autoinhibition. The DID also binds to the DAD regions of the diaphanous formins, downstream effectors of RhoA, inhibiting the activity of these actin regulators. All of the 40 some INF2 mutations reported to date localize to the DID, suggesting that loss of inhibition of INF2 own activity, or the activity of other formins (or both) may be critical to the mechanism of this form of disease. Subsets of patients with INF2 mutants also have Charcot Marie Tooth disease, a peripheral demyelinating condition ${ }^{5}$. There does not appear to be a clear difference in the nature of the mutations associated with FSGS alone versus those with Charcot Marie Tooth disease.

By positional cloning efforts in large multiplex families, FSGS-causing mutations were identified in the alpha-actinin-4 gene ACTN4 and in the TRPC6 cation channel gene ${ }^{6,7}$. The ACTN4 and TRPC6 associated phenotypes are similar: proteinuria, typically in the nonnephrotic range, and progressive chronic kidney disease. ACTN4 encodes an actin crosslinking protein alpha-actinin-4 that forms head-to-tail dimers with actin binding domain at each end. FSGS-associated mutations localize to the N-terminal actin-binding domain of the protein. These point mutations cause an increase in actin-binding affinity of these rod shaped dimers, likely causing changes in cytoskeletal biophysical properties and actin dynamics within cells ${ }^{8}$.

TRPC6 is a cation channel. Mutations in TRPC6 appear to be gain-of-function, leading to dominant disease through increased channel activity ${ }^{7,9}$. TRPC6 mediated calcium flux may activate RhoA signaling in cells ${ }^{10}$. This observation adds to the notion that altered small GTPase signaling is a common theme in podocyte dysfunction. Gain-of-function mutations in TRPC6 have also been shown to activate extracellular signal-regulated kinases 1/2 (ERK1/2) and cause constitutive activation of NFAT-dependent transcription ${ }^{11,12}$.

Several FSGS genes have been identified by mutational analyses of candidate genes, chosen for examination based on known roles in glomerular biology. ARHGAP24, encoding the FilGAP protein, was examined for disease-associated variants because of its expression pattern in podocytes. ARHGAP24 encodes a GTPase activating protein that is activated by RhoA. Analysis of this gene in FSGS families identified one family in which a mutation interfered with the activity of FilGAP and segregated with disease ${ }^{13}$. Similarly, the CD2AP gene has been analyzed for disease-associated variation based on its role in podocyte and slit-diaphragm function ${ }^{14}$. Mutational analysis in DNA from FSGS patients identified two 
individuals with a mutation predicted to ablate expression of one CD2AP allele, consistent with the notion that haploinsufficiency of CD2AP can contribute to the development of FSGS under a dominant model of inheritance. By contrast, Lowik et al identified a homozygous mutation encoding a premature stop codon in the CD2AP gene, consistent with an autosomal recessive form of $\mathrm{CD} 2 \mathrm{AP}$ associated FSGS ${ }^{15}$.

WT1, named for its role in Wilms' tumor, plays a critical role in kidney development ${ }^{16}$. Mutations in WT1 typically lead to the syndromic forms of kidney disease known as Frasier Syndrome and Denys Drash Syndrome. WT1 mutations can also rarely cause isolated nephrotic syndrome following autosomal dominant inheritance ${ }^{17-21}$. Frasier syndrome is characterized by steroid resistant nephrotic syndrome in childhood with histologic findings of FSGS, progressive CKD, male pseudohermaphroditism, and a high rate of gonadoblastomas. Denys Drash affected individuals display steroid resistant nephrosis in infancy with histologic findings of mesangial sclerosis. Denys-Drash patients progress to kidney failure and manifest ambiguous genitalia and nephroblastoma (Wilms' tumor). Mutations altering the three amino acids KTS (lysine, threonine, serine) in the splice site in intron 9 can cause isolated nephrotic syndrome with the absence of Wilms' tumor in 46, XX phenotypically concordant females ${ }^{19}$. Missense mutations in exons 8 and 9 of WT1 have been detected in patients with isolated diffuse mesangial sclerosis (DMS) ${ }^{22}$.

\section{Recessive forms of FSGS}

Inheritance of two mutant copies of several genes can cause recessive forms of FSGS/NS. In general, these recessive forms of disease present at earlier ages and are more aggressive than the autosomal dominant forms. Positional cloning studies in neonates with congenital nephrotic syndrome of the Finnish type led to the identification of mutations in the gene NPHS1, encoding nephrin, as the genetic cause ${ }^{23}$. Nephrin is a transmembrane protein that serves structural and signaling functions ${ }^{24}$. Typically, inheritance of two pathogenic NPHS2 mutations causes severe congenital nephrosis, with loss of podocyte foot process architecture and obliteration of a recognizable slit diaphragm ${ }^{23}$. Further studies suggest that the phenotypic spectrum of nephrin-associated disease is broader than originally observed, with some individuals presenting in childhood, or rarely, with FSGS in adulthood 25,26 . Close to 200 pathogenic NPHS1 mutations have been identified to date.

Positional cloning efforts also identified the NPHS2 gene, encoding podocin, as a relatively common cause of autosomal recessive steroid resistant nephrotic syndrome and FSGS in early childhood ${ }^{27}$. People with two pathogenic NPHS2 mutations tend to present with nephrotic syndrome between 3 months and 6 years of life, though some individuals present with congenital nephrosis and others with adult onset FSGS ${ }^{28,29}$. Certain specific NPHS2 variants appear more likely to cause disease at an earlier age, specifically frameshift, nonsense, and homozygous R138Q missense mutations ${ }^{30-35}$. NPHS2-associated disease is resistant to glucocorticoids and other immunosuppressive therapy. Patients with NPHS2associated disease have a reduced risk for recurrence of FSGS after kidney transplantation compared with idiopathic FSGS $27,32,36,37$. Mutations in NPHS2 have been found to be causal in 6-17\% of sporadic cases and $28-39 \%$ of familial cases of SRNS. Later onset FSGS is typically observed in individuals who carry the common R229Q NPHS2 
polymorphism together with a second mutation ${ }^{29,34}$. This $\mathrm{R} 229 \mathrm{Q}$ variant has an allele frequency of about $3 \%$ in most populations. The podocin protein is a lipid raft component of the slit diaphragm ${ }^{38}$. Podocin interacts directly with nephrin and is required for nephrin localization and function ${ }^{39-41}$.

Homozygosity mapping in consanguinous families identified a locus for early onset nephrotic syndrome and diffuse mesangial sclerosis on chromosome 10, leading to the identification of the responsible gene, PLCE1 (phospholipase C epsilon 1). Both missense and truncating mutations have been identified in PLCE1. Later onset PLCE1-associated disease may manifest as FSGS on biopsy ${ }^{42}$.

Other recent studies utilizing high throughput genotyping and next-generation sequencing in consanguineous families have led to the identification of additional autosomal recessive childhood nephrosis and/or proteinuria genes. These inlcude the myosin 1E gene MYO1E, the Nei endonuclease VIII-like 1 gene NEIL1, the cubulin gene Cthe ADCK4 gene, and the RhoGDI alpha gene ${ }^{43-48}$. These forms of disease appear to be quite rare.

Data examining various therapies in genetic forms of FSGS and nephrotic syndrome is very limited. Although there appear to be occasional patients who do respond to immunosuppression, this is rare. Most patients with NPHS1 or NPHS2 mutations do not respond to immunosuppression. Genetic testing may therefore guide the decision of how to treat an affected individual. Little information exists with regard to treatment response in autosomal dominant forms of FSGS caused by mutations in TRPC6, ACTN4, and INF2 but anecdotal information suggests that these forms of disease do not respond to immunosuppression.

\section{APOL1 and FSGS in the African Diaspora}

FSGS is particularly common in people of recent African ancestry. Genome wide association studies (GWAS) using mapping by admixture methods identified a genetic susceptibility locus on chromosome $22^{49,50}$. Two coding variants in the APOL1 drive this association $^{51,52}$. These variants, termed G1 and G2, in the APOL1 gene confer increased risk of developing FSGS, hypertension-associated kidney disease, or HIV nephropathy $(\text { HIVAN })^{51,52}$. G1 denotes the pair of missense variants encoding amino acid changes S342G and I384M that are almost always inherited together; G2 denotes a 6 base pair deletion leading to the in frame deletion of two amino acids near the $\mathrm{C}$ terminus of the protein. Individuals homozygous or compound heterozygous for these alleles have a 7-10 fold increased risk of developing FSGS or hypertension-associated ESRD. Those individuals with two APOL1 risk alleles have an odds ratio as high as 30 for developing HIV-associated FSGS $^{51,53,54}$. These two risk alleles are common in people of recent African ancestry, with a combined allele frequency of approximately $35 \%$ in African Americans ${ }^{54}$. The wild-type form of the APOL1 protein provides a form of innate immunity against trypanosoma $b$. brucei but not trypanosoma $b$. rhodesiense. The G1 and G2 variants show enhanced lytic activity against the African Sleeping Sickness pathogen trypanosoma b. rhodesiense, perhaps leading to positive selective pressures on these alleles. The mechanisms by which these variants in APOL1 cause kidney disease remains unknown. Because of the high 
frequency of G1 and G2 as well as the large increased risk of FSGS associated with these variants, families in which multiple individuals have FSGS or ESRD may have APOL1associated disease, rather than one of the rarer Mendelian forms of disease described above.

\section{Conclusions}

It is important for the clinician to remember that FSGS is a pathologically defined entity, rather than a specific disease. A broad range inherited syndromes may include FSGS as a component or a downstream effect of the primary biological lesion. Thus, individuals with, for example, various forms of nephronophthisis, glomerular basement membrane disorders, and mitochondrial diseases, may all exhibit proteinuria, chronic kidney disease, and FSGS. Thus, careful clinical phenotyping is a critical component in the accurate diagnosis of inherited forms of FSGS.

\section{References}

1. Brown EJ, Schlondorff JS, Becker DJ, et al. Mutations in the formin gene INF2 cause focal segmental glomerulosclerosis. Nat Genet. 2010; 42(1):72-76. [PubMed: 20023659]

2. Gbadegesin RA, Lavin PJ, Hall G, et al. Inverted formin 2 mutations with variable expression in patients with sporadic and hereditary focal and segmental glomerulosclerosis. Kidney Int. 2012; 81(1):94-99. [PubMed: 21866090]

3. Boyer O, Benoit G, Gribouval O, et al. Mutations in INF2 are a major cause of autosomal dominant focal segmental glomerulosclerosis. J Am Soc Nephrol. 2011; 22(2):239-245. [PubMed: 21258034]

4. Barua M, Brown EJ, Charoonratana VT, Genovese G, Sun H, Pollak MR. Mutations in the INF2 gene account for a significant proportion of familial but not sporadic focal and segmental glomerulosclerosis. Kidney Int. 2013; 83(2):316-322. [PubMed: 23014460]

5. Boyer O, Nevo F, Plaisier E, et al. INF2 mutations in Charcot-Marie-Tooth disease with glomerulopathy. The New England journal of medicine. 2011; 365(25):2377-2388. [PubMed: 22187985]

6. Kaplan JM, Kim SH, North KN, et al. Mutations in ACTN4, encoding alpha-actinin-4, cause familial focal segmental glomerulosclerosis. Nat Genet. 2000; 24(3):251-256. [PubMed: 10700177]

7. Winn MP, Conlon PJ, Lynn KL, et al. A mutation in the TRPC6 cation channel causes familial focal segmental glomerulosclerosis. Science. 2005; 308(5729):1801-1804. [PubMed: 15879175]

8. Weins A, Schlondorff JS, Nakamura F, et al. Disease-associated mutant alpha-actinin-4 reveals a mechanism for regulating its F-actin-binding affinity. Proc Natl Acad Sci U S A. 2007; 104(41): 16080-16085. [PubMed: 17901210]

9. Reiser J, Polu KR, Moller CC, et al. TRPC6 is a glomerular slit diaphragm-associated channel required for normal renal function. Nat Genet. 2005; 37(7):739-744. [PubMed: 15924139]

10. Tian D, Jacobo SM, Billing D, et al. Antagonistic regulation of actin dynamics and cell motility by TRPC5 and TRPC6 channels. Sci Signal. 2010; 3(145):ra77. [PubMed: 20978238]

11. Schlondorff J, Del Camino D, Carrasquillo R, Lacey V, Pollak MR. TRPC6 mutations associated with focal segmental glomerulosclerosis cause constitutive activation of NFAT-dependent transcription. Am J Physiol Cell Physiol. 2009; 296(3):C558-569. [PubMed: 19129465]

12. Chiluiza D, Krishna S, Schumacher VA, Schlondorff J. Gain-of-function mutations in transient receptor potential C6 (TRPC6) activate extracellular signal-regulated kinases 1/2 (ERK1/2). J Biol Chem. 2013; 288(25):18407-18420. [PubMed: 23645677]

13. Akilesh S, Suleiman H, Yu H, et al. Arhgap24 inactivates Rac1 in mouse podocytes, and a mutant form is associated with familial focal segmental glomerulosclerosis. J Clin Invest. 2011; 121(10): 4127-4137. [PubMed: 21911940]

14. Kim JM, Wu H, Green G, et al. CD2-associated protein haploinsufficiency is linked to glomerular disease susceptibility. Science. 2003; 300(5623):1298-1300. [PubMed: 12764198] 
15. Lowik MM, Groenen PJ, Pronk I, et al. Focal segmental glomerulosclerosis in a patient homozygous for a CD2AP mutation. Kidney Int. 2007; 72(10):1198-1203. [PubMed: 17713465]

16. Kreidberg JA, Hartwig S. Wilms' tumor-1: a riddle wrapped in a mystery, inside a kidney. Kidney Int. 2008; 74(4):411-412. [PubMed: 18670405]

17. Pelletier J, Bruening W, Li FP, Haber DA, Glaser T, Housman DE. WT1 mutations contribute to abnormal genital system development and hereditary Wilms' tumour. Nature. 1991; 353(6343): 431-434. [PubMed: 1654525]

18. Barbaux S, Niaudet P, Gubler MC, et al. Donor splice-site mutations in WT1 are responsible for Frasier syndrome. Nat Genet. 1997; 17(4):467-470. [PubMed: 9398852]

19. Ruf RG, Schultheiss M, Lichtenberger A, et al. Prevalence of WT1 mutations in a large cohort of patients with steroid-resistant and steroid-sensitive nephrotic syndrome. Kidney Int. 2004; 66(2): 564-570. [PubMed: 15253707]

20. Mucha B, Ozaltin F, Hinkes BG, et al. Mutations in the Wilms' tumor 1 gene cause isolated steroid resistant nephrotic syndrome and occur in exons 8 and 9. Pediatr Res. 2006; 59(2):325-331. [PubMed: 16439601]

21. Niaudet P, Gubler MC. WT1 and glomerular diseases. Pediatr Nephrol. 2006; 21(11):1653-1660. [PubMed: 16927106]

22. Jeanpierre C, Denamur E, Henry I, et al. Identification of constitutional WT1 mutations, in patients with isolated diffuse mesangial sclerosis, and analysis of genotype/phenotype correlations by use of a computerized mutation database. Am J Hum Genet. 1998; 62(4):824-833. [PubMed: 9529364]

23. Kestila M, Lenkkeri U, Mannikko M, et al. Positionally cloned gene for a novel glomerular protein--nephrin--is mutated in congenital nephrotic syndrome. Molecular cell. 1998; 1(4):575582. [PubMed: 9660941]

24. Huber TB, Benzing T. The slit diaphragm: a signaling platform to regulate podocyte function. Current opinion in nephrology and hypertension. 2005; 14(3):211-216. [PubMed: 15821412]

25. Philippe A, Nevo F, Esquivel EL, et al. Nephrin mutations can cause childhood-onset steroidresistant nephrotic syndrome. J Am Soc Nephrol. 2008; 19(10):1871-1878. [PubMed: 18614772]

26. Santin S, Garcia-Maset R, Ruiz P, et al. Nephrin mutations cause childhood- and adult-onset focal segmental glomerulosclerosis. Kidney Int. 2009; 76(12):1268-1276. [PubMed: 19812541]

27. Boute N, Gribouval O, Roselli S, et al. NPHS2, encoding the glomerular protein podocin, is mutated in autosomal recessive steroid-resistant nephrotic syndrome. Nat Genet. 2000; 24(4):349354. [PubMed: 10742096]

28. Hinkes BG, Mucha B, Vlangos CN, et al. Nephrotic syndrome in the first year of life: two thirds of cases are caused by mutations in 4 genes (NPHS1, NPHS2, WT1, and LAMB2). Pediatrics. 2007; 119(4):e907-919. [PubMed: 17371932]

29. Tsukaguchi H, Sudhakar A, Le TC, et al. NPHS2 mutations in late-onset focal segmental glomerulosclerosis: R229Q is a common disease-associated allele. J Clin Invest. 2002; 110(11): 1659-1666. [PubMed: 12464671]

30. Benoit G, Machuca E, Nevo F, Gribouval O, Lepage D, Antignac C. Analysis of recessive CD2AP and ACTN4 mutations in steroid-resistant nephrotic syndrome. Pediatr Nephrol. 2010; 25(3):445451. [PubMed: 19956976]

31. Hinkes B, Vlangos C, Heeringa S, et al. Specific podocin mutations correlate with age of onset in steroid-resistant nephrotic syndrome. J Am Soc Nephrol. 2008; 19(2):365-371. [PubMed: 18216321]

32. Weber S, Gribouval O, Esquivel EL, et al. NPHS2 mutation analysis shows genetic heterogeneity of steroid-resistant nephrotic syndrome and low post-transplant recurrence. Kidney Int. 2004; 66(2):571-579. [PubMed: 15253708]

33. Tonna SJ, Needham A, Polu K, et al. NPHS2 variation in focal and segmental glomerulosclerosis. BMC Nephrol. 2008; 9:13. [PubMed: 18823551]

34. Machuca E, Hummel A, Nevo F, et al. Clinical and epidemiological assessment of steroid-resistant nephrotic syndrome associated with the NPHS2 R229Q variant. Kidney Int. 2009; 75(7):727-735. [PubMed: 19145239] 
35. Santin S, Tazon-Vega B, Silva I, et al. Clinical value of NPHS2 analysis in early- and adult-onset steroid-resistant nephrotic syndrome. Clin J Am Soc Nephrol. 2011; 6(2):344-354. [PubMed: 20947785]

36. Ruf RG, Lichtenberger A, Karle SM, et al. Patients with mutations in NPHS2 (podocin) do not respond to standard steroid treatment of nephrotic syndrome. J Am Soc Nephrol. 2004; 15(3):722732. [PubMed: 14978175]

37. Jungraithmayr TC, Hofer K, Cochat P, et al. Screening for NPHS2 mutations may help predict FSGS recurrence after transplantation. J Am Soc Nephrol. 2011; 22(3):579-585. [PubMed: 21355056]

38. Schwarz K, Simons M, Reiser J, et al. Podocin, a raft-associated component of the glomerular slit diaphragm, interacts with CD2AP and nephrin. J Clin Invest. 2001; 108(11):1621-1629. [PubMed: 11733557]

39. Roselli S, Gribouval O, Boute N, et al. Podocin localizes in the kidney to the slit diaphragm area. Am J Pathol. 2002; 160(1):131-139. [PubMed: 11786407]

40. Huber TB, Kottgen M, Schilling B, Walz G, Benzing T. Interaction with podocin facilitates nephrin signaling. J Biol Chem. 2001; 276(45):41543-41546. [PubMed: 11562357]

41. Huber TB, Simons M, Hartleben B, et al. Molecular basis of the functional podocin-nephrin complex: mutations in the NPHS2 gene disrupt nephrin targeting to lipid raft microdomains. Human molecular genetics. 2003; 12(24):3397-3405. [PubMed: 14570703]

42. Hinkes B, Wiggins RC, Gbadegesin R, et al. Positional cloning uncovers mutations in PLCE1 responsible for a nephrotic syndrome variant that may be reversible. Nat Genet. 2006; 38(12): 1397-1405. [PubMed: 17086182]

43. Ovunc B, Otto EA, Vega-Warner V, et al. Exome sequencing reveals cubilin mutation as a singlegene cause of proteinuria. J Am Soc Nephrol. 2011; 22(10):1815-1820. [PubMed: 21903995]

44. Mele C, Iatropoulos P, Donadelli R, et al. MYO1E mutations and childhood familial focal segmental glomerulosclerosis. The New England journal of medicine. 2011; 365(4):295-306. [PubMed: 21756023]

45. Sanna-Cherchi S, Burgess KE, Nees SN, et al. Exome sequencing identified MYO1E and NEIL1 as candidate genes for human autosomal recessive steroid-resistant nephrotic syndrome. Kidney Int. 2011; 80(4):389-396. [PubMed: 21697813]

46. Gee HY, Saisawat P, Ashraf S, et al. ARHGDIA mutations cause nephrotic syndrome via defective RHO GTPase signaling. J Clin Invest. 2013; 123(8):3243-3253. [PubMed: 23867502]

47. Gupta IR, Baldwin C, Auguste D, et al. ARHGDIA: a novel gene implicated in nephrotic syndrome. J Med Genet. 2013; 50(5):330-338. [PubMed: 23434736]

48. Ashraf S, Gee HY, Woerner S, et al. ADCK4 mutations promote steroid-resistant nephrotic syndrome through CoQ10 biosynthesis disruption. J Clin Invest. 2013; 123(12):5179-5189. [PubMed: 24270420]

49. Kopp JB, Smith MW, Nelson GW, et al. MYH9 is a major-effect risk gene for focal segmental glomerulosclerosis. Nat Genet. 2008; 40(10):1175-1184. [PubMed: 18794856]

50. Kao WH, Klag MJ, Meoni LA, et al. MYH9 is associated with nondiabetic end-stage renal disease in African Americans. Nat Genet. 2008; 40(10):1185-1192. [PubMed: 18794854]

51. Genovese G, Friedman DJ, Ross MD, et al. Association of trypanolytic ApoL1 variants with kidney disease in African Americans. Science. 2010; 329(5993):841-845. [PubMed: 20647424]

52. Tzur S, Rosset S, Shemer R, et al. Missense mutations in the APOL1 gene are highly associated with end stage kidney disease risk previously attributed to the MYH9 gene. Hum Genet. 2010; 128(3):345-350. [PubMed: 20635188]

53. Kopp JB, Nelson GW, Sampath K, et al. APOL1 genetic variants in focal segmental glomerulosclerosis and HIV-associated nephropathy. J Am Soc Nephrol. 2011; 22(11):2129-2137. [PubMed: 21997394]

54. Friedman DJ, Kozlitina J, Genovese G, Jog P, Pollak MR. Population-based risk assessment of APOL1 on renal disease. J Am Soc Nephrol. 2011; 22(11):2098-2105. [PubMed: 21997396] 


\section{Table}

\begin{tabular}{|c|c|c|c|c|}
\hline Gene & Locus & Inheritance & Protein & Phenotype \\
\hline \multicolumn{5}{|l|}{ Slit diaphragm } \\
\hline NPHS1 & $19 \mathrm{q} 13.1$ & $\mathrm{AR}$ & Nephrin & Congenital nephrotic syndrome \\
\hline NPHS2 & $1 \mathrm{q} 25.2$ & $\mathrm{AR}$ & Podocin & Congenital, infant, childhood onset SRNS, FSGS. \\
\hline PLCE1 & $10 \mathrm{q} 23.33$ & AR & Phospholipase $\mathrm{C}$ epsilon 1 & Early onset DMS. FSGS. \\
\hline$C D 2 A P$ & $6 \mathrm{p} 12$ & $\mathrm{AD}$ & $\mathrm{CD} 2$ associated protein & FSGS. CD2AP deficient mouse model develops severe proteinuria \\
\hline TRPC6 & $11 \mathrm{q} 22.1$ & $\mathrm{AD}$ & TRPC6 & Adult onset FSGS \\
\hline \multicolumn{5}{|c|}{ Actin cytoskeleton } \\
\hline ACTN4 & $19 \mathrm{q} 13$ & $\mathrm{AD}$ & Alpha-actinin 4 & Adult onset FSGS \\
\hline$I N F 2$ & $14 \mathrm{q} 32.33$ & $\mathrm{AD}$ & Inverted formin 2 & Adult onset FSGS \\
\hline MYOIE & $15 \mathrm{q} 22.2$ & $\mathrm{AR}$ & Myosin 1E & Childhood onset SRNS \\
\hline ARHGAP24 & $4 \mathrm{q} 22.1$ & $\mathrm{AD}$ & Arhgap24 (RhoGAP) & Adolescent onset FSGS \\
\hline ARHGDIA & $17 \mathrm{q} 25.3$ & $\mathrm{AR}$ & $\underline{\text { Arhgdia }}$ & Childhood onset SRNS \\
\hline \multicolumn{5}{|l|}{ Nuclear } \\
\hline$W T 1$ & $11 \mathrm{p} 13$ & $\mathrm{AD}$ & Wilms' tumor 1 & Frasier or Denys Drash syndrome or isolated NS \\
\hline \multicolumn{5}{|l|}{ Other } \\
\hline$A P O L 1$ & 22q13.1 & $\mathrm{AR}$ & Apolipoprotein 1 & High risk of FSGS and ESKD in African Americans \\
\hline
\end{tabular}

Genetic causes of FSGS and steroid resistant nephrotic syndrome

$\mathrm{AD}=$ autosomal dominant

$\mathrm{AR}=$ autosomal recessive

DMS $=$ diffuse mesangial sclerosis. 